\title{
The impact of red blood cell storage duration on tissue oxygenation in cardiac surgery
}

\author{
Christopher P. Stowell, MD, PhD, ${ }^{a}$ Glenn Whitman, MD, ${ }^{b}$ Suzanne Granger, MS, ${ }^{c}$ \\ Hernando Gomez, MD, MPH, ${ }^{\mathrm{d}}$ Susan F. Assmann, PhD, ${ }^{\mathrm{c}}$ Michael J. Massey, PhD, \\ Nathan I. Shapiro, MD, MPH, ${ }^{\mathrm{e}, \mathrm{f}}$ Marie E. Steiner, MD, MS, ${ }^{\mathrm{g}}$ and Elliott Bennett-Guerrero, $\mathrm{MD}^{\mathrm{h}}$
}

\begin{abstract}
Objective: Although storage alters red blood cells, several recent, randomized trials found no differences in clinical outcomes between patients transfused with red blood cells stored for shorter versus longer periods of time. The objective of this study was to see whether storage impairs the in vivo ability of erythrocytes to traverse the microcirculation and deliver oxygen at the tissue level.

Methods: A subset of subjects from a clinical trial of cardiac surgery patients randomized to receive transfusions of red blood cells stored $\leq 10$ days or $\geq 21$ days were assessed for thenar eminence and cerebral tissue hemoglobin oxygen saturation $\left(\mathrm{S}_{\mathrm{t}} \mathrm{O}_{2}\right)$ via the use of near-infrared spectroscopy and sublingual microvascular blood flow via side-stream darkfield videomicroscopy.
\end{abstract}

Results: Among 55 subjects, there was little change in the primary endpoint (thenar eminence $\mathrm{S}_{\mathrm{t}} \mathrm{O}_{2}$ from before to after transfusion of one unit) and the change was similar in the 2 groups: $+1.7 \%$ (95\% confidence interval, $-0.3,3.8)$ for shorter-storage and $+0.8 \%(95 \%$ confidence interval, $-1.1,2.9)$ for longerstorage; $P=.61$ ). Similarly, no significant differences were observed for cerebral $\mathrm{S}_{\mathrm{t}} \mathrm{O}_{2}$ or sublingual microvascular blood flow. These parameters also were not different from preoperatively to 1 day postoperatively, reflecting the absence of a cumulative effect of all red blood cell units transfused during this period.

Conclusions: There were no differences in thenar eminence or cerebral $\mathrm{S}_{\mathrm{t}} \mathrm{O}_{2}$, or sublingual microcirculatory blood flow, in cardiac surgery patients transfused with red blood cells stored $\leq 10$ days or $\geq 21$ days. These results are consistent with the clinical outcomes in the parent study, which also did not differ, indicating that storage may not impair oxygen delivery by red blood cells in this setting. ( $\mathrm{J}$ Thorac Cardiovasc Surg 2017;153:610-9)

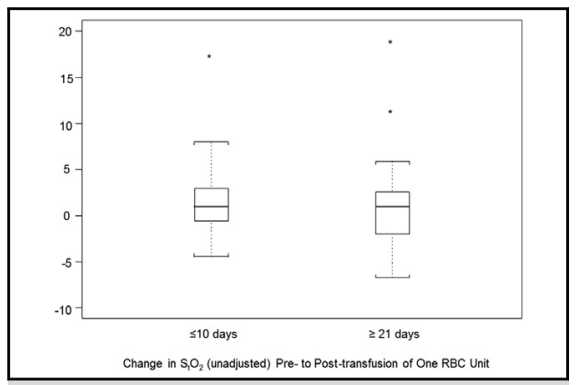

Change in thenar eminence tissue hemoglobin oxygen saturation Pre- to Posttransfusion of red blood cells stored $\leq 10$ days or $\geq 21$ days.

\section{Central Message}

Red cell storage did not impair tissue oxygenation or microcirculation in cardiac surgery patients, consistent with lack of difference in clinical outcomes.

\section{Perspective}

The impact of red cell storage on clinical outcomes has been controversial, but recent randomized trials have demonstrated no differences between patients receiving red cells stored for shorter versus longer periods. In a subset of cardiac surgery patients in one of these trials, we found no differences in tissue oxygenation and microcirculatory blood flow, consistent with the clinical outcomes.

See Editorial Commentary page 620.
The changes occurring in red blood cells (RBCs) under conventional storage conditions have been well described ${ }^{1}$ and have led to the hypothesis that they might impair RBC function in the transfusion recipient. ${ }^{2}$ A number of observational, usually retrospective, studies comparing clinical outcomes in patients receiving RBCs stored for different

From the ${ }^{a}$ Blood Transfusion Service, Department of Pathology, Massachusetts General Hospital, Harvard Medical School; ${ }^{b}$ Division of Cardiac Surgery, Department of Surgery, Johns Hopkins Hospital, Baltimore, Md; ${ }^{\mathrm{c}}$ New England Research Institutes, Watertown; ${ }^{\mathrm{d}}$ Department of Critical Care Medicine, Center for Critical

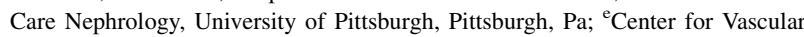
Biology Research, Beth Israel Deaconess Medical Center; ${ }^{\mathrm{f}}$ Harvard Medical School, Boston, Mass; ${ }^{\mathrm{g}}$ Department of Pediatrics, University of Minnesota, Minneapolis, Minn; and ${ }^{\mathrm{h}}$ Department of Anesthesiology, Duke University Medical Center, Durham, NC.

Supported by the National Heart,Lung and Blood Institute; 1 R01 HL101382-01; the Evelyn and Robert Luick Memorial Fund (to C.P.S.); and K12 HL109068-02 (to

H.G.). None of the sponsors participated in the design of the study, collecting, analyzing and interpreting the data, writing the report or deciding to submit the report for publication.

Received for publication Jan 30, 2016; revisions received Oct 7, 2016; accepted for publication Nov 5, 2016; available ahead of print Dec 24, 2016.

Address for reprints: Christopher P. Stowell, MD, PhD, Blood Transfusion Service, GRJ-148, Massachusetts General Hospital, 55 Fruit St, Boston, MA 02114 (E-mail: cstowell@partners.org). $0022-5223 / \$ 36.00$

Copyright $(2016$ by The American Association for Thoracic Surgery http://dx.doi.org/10.1016/j.jtcvs.2016.11.029 


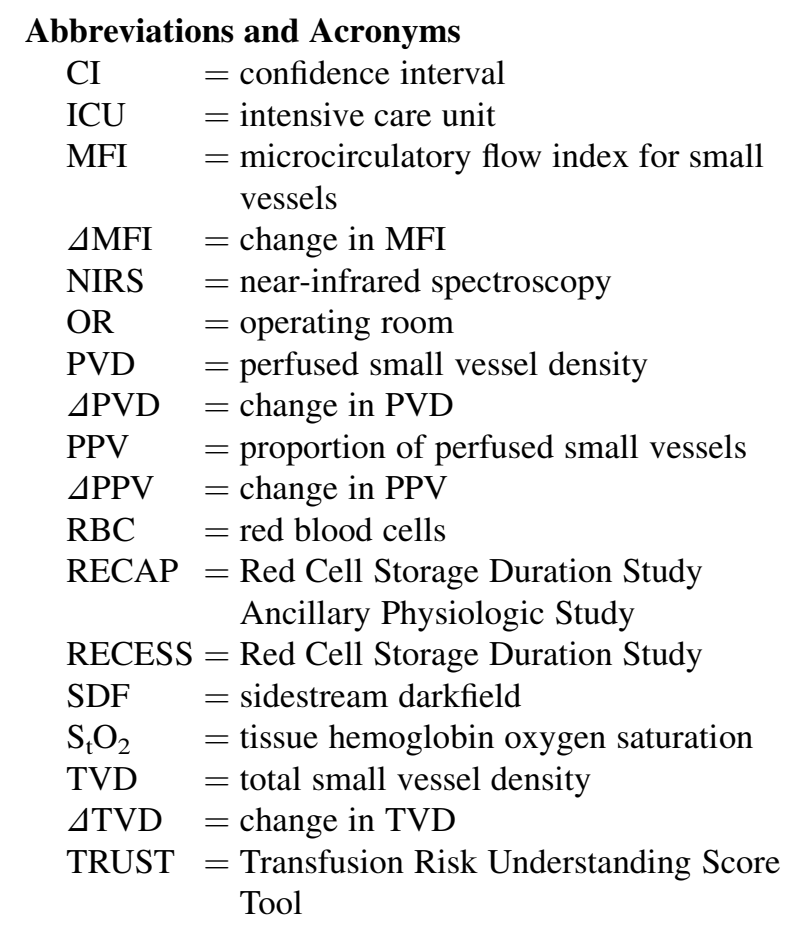

Scanning this QR code will take you to supplemental tables, video, and appendix for this article. objective of the National Institutes of Health-funded Red Cell Storage Duration Study Ancillary Physiologic Study (RECAP) was to determine whether the storage duration of RBCs affects tissue oxygen saturation of hemoglobin, as measured by near-infrared spectroscopy (NIRS), and microcirculatory blood flow, as measured using sidestream darkfield (SDF) videomicroscopy, in patients who had undergone complex cardiac surgery, and whether these measurements would be consistent with the clinical outcomes observed in the parent trial. The intention of this study was to examine events at the tissue level that might provide insight into the apparent paradox between the well-documented changes that occur to RBCs during storage and the lack of measurable clinical impact.

\section{MATERIALS AND METHODS \\ Oversight}

RECAP (NCT01274390) was a multicenter, prospective, clinical trial that enrolled patients at 4 sites belonging to the Transfusion Medicine and Hemostasis Clinical Trials Network. RECAP was conducted as an ancillary trial to a parent study carried out by the network, RECESS (NCT00991341) and was funded independently by National Heart, Lung, and Blood Institute/National Institutes of Health with no commercial support. The 4 enrolling sites for RECAP were Duke University, the Johns Hopkins University, Massachusetts General Hospital, and the University of Pittsburgh. The Data Statistical Coordinating Center was New England Research Institutes. The study was designed by the authors and approved by the institutional review boards at each participating hospital. Study subjects provided written informed consent. The same data and safety monitoring board oversaw the parent study and RECAP. This study received the following institutional review board approvals: Duke University Medical Center, 12/07/2009 21198; Johns Hopkins Hospital, 10/25/2012 NA_00075888; Massachusetts General Hospital, 04/07/2010 2009 P002612/1; University of Pittsburgh, 09/12/2012 PRO12060386; and New England Research Institutes, 03/18/2010 \#788.10.

\section{Study Patients}

The patients participating in this study were a subset of subjects who were enrolled in the RECESS study at 4 of the participating sites. Patients were eligible for the parent study ${ }^{11}$ if they were scheduled for complex cardiac surgery via median sternotomy and were likely to require RBC transfusion as determined by a Transfusion Risk Understanding Score Tool (TRUST) of 3 or greater. ${ }^{17}$ Additional eligibility criteria for RECAP were age at least 18 years and scheduled coronary artery bypass grafting, valve repair or replacement, or a combination. Patients were approached and consented for RECAP at the same time they were consented for the parent study. Randomization could not be done any earlier than the day before surgery. Subjects who could not be randomized were no longer eligible for RECAP.

\section{Study Design and Treatment Protocols}

For the parent study, subjects were assigned randomly, in a 1:1 ratio, to receive units of $\mathrm{RBCs}$ stored for $\leq 10$ days or $\geq 21$ days for all transfusions from the time of randomization through the earliest of day 28 , death, or discharge from the hospital. Randomization was balanced by site ${ }^{18}$ with the use of a centralized computer system. All units were prestorage leukoreduced RBCs collected in standard, licensed additive solution systems and were not irradiated or washed. The expiration dates of the units were not obscured, but the central laboratory (Shapiro Laboratory, Center for Vascular Biology Research, Beth Israel Deaconess Medical Center, Boston, Mass), which analyzed the primary raw electronic data files for the oxygenation and microcirculatory flow measurements, was blinded to study arm assignment. 


\section{Assessments, Monitoring, and Outcome Measures}

Tissue hemoglobin oxygen saturation. The oxygen saturation of tissue hemoglobin $\left(\mathrm{S}_{\mathrm{t}} \mathrm{O}_{2}\right)$ was measured with NIRS. Sensors were applied to the patient's thenar eminence (InSpectra 650; Hutchinson Technology, Hutchinson, Minn) and forehead (Foresight; CAS Medical Systems, Branford, Conn) before the induction of general anesthesia and were left in place at least 24 hours after the patient left the operating room. Data were recorded continuously every 2 seconds, stored in the devices, and then were transferred to the central laboratory for analysis via a proprietary file transfer software (Studymaker Microscan File Manager, Studymaker, Newton, Mass). Analysis of the raw data is described in Appendix E1.

Microcirculatory blood flow. The sublingual microcirculation was visualized with SDF videomicroscopy (Microscan; Microvision Medical, Inc, Amsterdam, The Netherlands) as previously described. ${ }^{19}$ Multiple videoclips of up to a minute each were captured at the 4 time points defined herein. The videoclips were stored on a laptop computer and uploaded to the central laboratory by use of the same proprietary file transfer software and cloud storage. Details of the processing and analysis of the videoscans are described in Appendix E1. The microcirculatory parameters reported in this study were proportion of perfused small vessels (PPV) and the change in PPV ( $\triangle \mathrm{PPV})$; microcirculatory flow index for small vessels (MFI and $\triangle \mathrm{MFI}$ ); perfused small vessel density (PVD and $\triangle \mathrm{PVD}$ ); and total small vessel density (TVD and $\triangle T V D$ ). For the perfusion parameters (PPV, $\triangle \mathrm{PPV}, \mathrm{PVD}, \triangle \mathrm{PVD}$ ), any vessel segment with a flow score greater than or equal to 2 (sluggish or continuous flow) was considered perfused. Following the guidelines of a consensus report, we estimated MFI as the average over 4 quadrants of the field of view of the most prominent flow in the vessels that occupied each quadrant. ${ }^{20}$

Timing of measurements. Measurements were made at 4 time points: within 6 hours before surgery; within 2 hours before a postoperative $\mathrm{RBC}$ transfusion that took place in the intensive care unit (ICU) at any point within the 24 hours after surgery; within 2 hours after that postoperative $\mathrm{RBC}$ transfusion; and $24 \pm 4$ hours after the end of surgery. If measurements could not be obtained before and after the first postoperative transfusion, or if the first transfusion included more than 1 unit, the measurements could be made before and after a subsequent RBC transfusion, as long as that single unit of RBC was transfused in the ICU within 24 hours after the conclusion of surgery. For each patient, the first RBC transfusion for which measurements could be obtained was considered the "index" transfusion. The measurements within 2 hours before and after the index transfusion were intended to capture transient changes in tissue oxygenation, whereas the preoperative and 24-hour postoperative measurements would reflect the cumulative impact of the transfusion of multiple units of RBCs.

\section{Statistical Analysis}

All analyses were conducted by a statistician (S.G.) at the Data and Statistical Coordinating Center (New England Research Institutes). Data on the changes in physiologic parameters were compared between treatment groups via analysis of covariance, with adjustment for the pretransfusion value. Binary and categorical variables were compared between treatment groups via the Fisher exact test, and effect sizes were calculated with the Cramer phi statistic. Continuous variables were compared with KruskalWallis tests, and effect sizes were calculated as the absolute difference in means divided by the pooled standard deviation.

The primary endpoint was the change in the peripheral $\mathrm{S}_{\mathrm{t}} \mathrm{O}_{2}$ from within 2 hours before transfusion to within 2 hours after a postoperative RBC transfusion in the ICU $\left(\Delta \mathrm{S}_{\mathrm{t}} \mathrm{O}_{2}\right)$. The protocol-defined secondary endpoints were the change in the cerebral oxygen saturation of hemoglobin and the changes in 4 parameters of microcirculatory blood flow ( $\triangle \mathrm{MFI}, \triangle \mathrm{PPV}$, $\triangle \mathrm{PVD}$, and $\triangle \mathrm{TVD}$ ) over this same time period. Other secondary outcomes were the changes in all 6 of these measurements from the period 6 hours before surgery to $24 \pm 4$ hours after surgery. No imputation was done for missing data points.
Subjects were considered to be analyzable for pre- to posttransfusion changes in a RECAP outcome if they had been randomized successfully in RECESS, underwent a cardiac surgical procedure, had an index transfusion in the ICU, and had valid data for the outcome being analyzed. Similarly, subjects were considered evaluable for changes from presurgery to 1 day postsurgery if they were randomized in RECESS, had surgery, received at least one RBC unit during this time period, and had valid data for the outcome. As specified in the protocol, an intention-to-treat analysis was conducted with data from all participants who met the criteria for evaluation listed previously, regardless of what storage-duration RBCs actually were received. Secondary per-protocol analyses were carried out in a similar way, including only subjects who received RBCs in accordance with their assigned treatment group from randomization through 1 day after surgery.

\section{RESULTS}

\section{Patients and Treatment Assignments}

Between January 2011 and January 2014, 130 subjects in the parent trial also consented to participate in RECAP (Figure 1). Of these, 7 were ineligible for RECAP: 2 had a planned surgical procedure that did not meet the inclusion criteria for RECAP, and 5 could not be randomized in RECESS because the blood bank could not meet the crossmatch request with units of RBC for both storage durations. There were 6 eligible RECAP subjects ( 3 in each treatment arm) who did not undergo surgery. Of the remaining subjects, 59 were randomized to the arm receiving RBC stored $\leq 10$ days, and 58 to the arm receiving RBC stored $\geq 21$ days. Of these, 23 in the $\leq 10$ days arm and 32 in the $\geq 21$ days arm received at least 1 unit of RBC within $24 \pm 4$ hours of leaving the operating room (OR) for which measurements could be obtained (index transfusions).

The baseline characteristics of patients in the 2 arms of the study were similar (Table 1), including the frequency of significant comorbidities and the distribution of $\mathrm{ABO}$ blood groups. The baseline Multiple Organ Dysfunction Score $^{21}$ was lower in the $\geq 21$ days arm $(P \leq .01)$ but the difference was less than 1.0 point and both values were very low. Serum creatinine also was lower in this group, but the levels were mostly within the reference range and the differences between the groups were small $(\leq 0.5 \mathrm{mg} / \mathrm{dL})$. The characteristics of the surgical procedures also were comparable between the 2 groups (Table 2). The baseline characteristics of the RECAP subjects were very similar to those for the parent study, RECESS, as a whole ${ }^{7}$ (Table E1).

\section{Transfusions}

The storage duration of the RBC units transfused to the RECAP patients intraoperatively and within 24 hours of leaving the OR is shown in Figure 2 and Table 3. The mean ( \pm standard deviation) storage duration for RBCs transfused to subjects assigned to receive units stored $\leq 10$ days was $8.2 \pm 4.7$ days; for units transfused to subjects in the $\geq 21$ day arm, the mean ( \pm standard deviation) storage duration was $27.9 \pm 7.4 \mathrm{~d}$. The median storage times (quartile 1, quartile 3) were 7 days $(6,9)$ and 


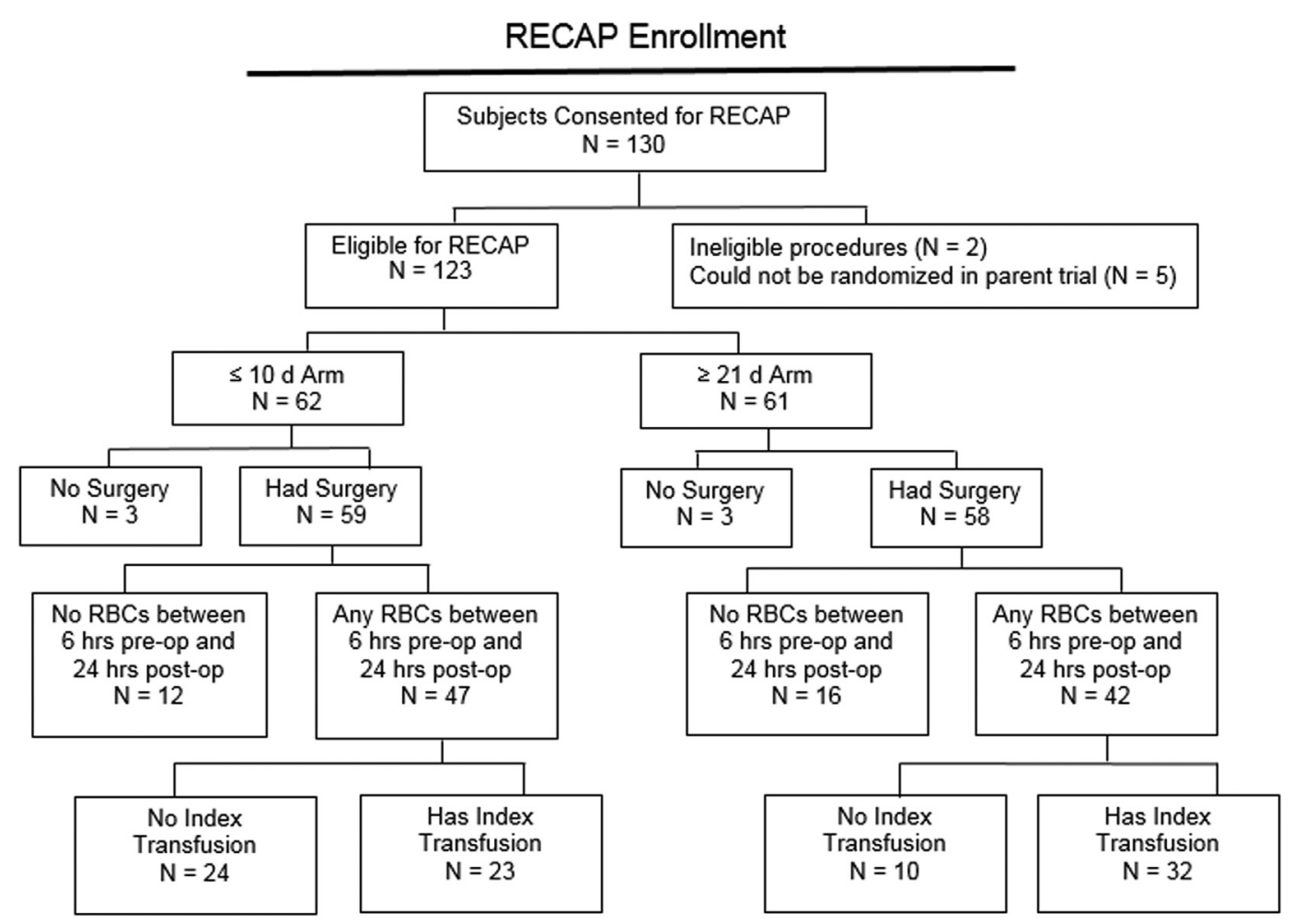

FIGURE 1. CONSORT diagram for the RECESS ancillary physiologic study. An index transfusion is the first postoperative single unit of RBCs for which the study measurements could be made. RECAP, Red Cell Storage Duration Study Ancillary Physiologic Study; RBCs, red blood cells.

28 days $(23,34)$ respectively. Adherence to the study arm assignment was high, with $92 \%$ of units transfused to subjects in the $\leq 10$ day arm and $93 \%$ of units transfused to subjects in the $\geq 21$ day arm meeting study requirements. Of the subjects in the shorter storage arm of the study, $87 \%$ received only units stored $\leq 10$ days, whereas $93 \%$ of subjects in the longer storage-arm received only units stored $\geq 21$ days.

The mean number of RBCs transfused up to and including the index transfusion, for subjects with an index transfusion, was $3.6 \pm 2.8$ units (median 3.0 units) in the $\leq 10$ day arm and $2.9 \pm 2.3$ units (median 2.5 units) in the $\geq 21$ day arm $(P=.30)$. The mean number of RBCs transfused through 24 hours postoperatively was greater than 4 units per subject for both groups, and a similar proportion of subjects received more than 6 units of RBCs (Table 3). The volumes of other blood components transfused to the patients in both arms also were similar.

\section{Physiologic Measurements}

As shown in Table E2, the subjects in the 2 arms of the study were comparable with respect to several key clinical characteristics within 2 hours preceding the transfusion of a single unit of RBC in the ICU postoperatively: systolic and diastolic blood pressure, heart rate, blood $\mathrm{O}_{2}$ saturation, and level of respiratory and inotropic support. Figure 3 and
Table 4 show the results of the $\mathrm{S}_{\mathrm{t}} \mathrm{O}_{2}$ measurements at the thenar eminence as determined by NIRS within 2 hours before and after transfusion of this postoperative RBC transfusion, time points that might be expected to detect real, albeit transient, changes in tissue oxygenation. Before the postoperative $\mathrm{RBC}$ transfusion, the 2 groups of patients also showed similar levels of thenar eminence $\mathrm{S}_{\mathrm{t}} \mathrm{O}_{2}$ with means of approximately $78 \%$. After transfusion of one unit of $\mathrm{RBC}$, the $\mathrm{S}_{\mathrm{t}} \mathrm{O}_{2}$ levels were again comparable between the 2 groups, with very little change compared to the pretransfusion levels. The change in $\mathrm{S}_{\mathrm{t}} \mathrm{O}_{2}$ from pre- to posttransfusion was only an increase of $1.7 \%$ (95\% confidence interval $[\mathrm{CI}],-0.3,3.8)$ in the $\leq 10$ days group and $0.8 \%(95 \% \mathrm{CI},-1.1,2.7)$ in the $\geq 21$ day group; the difference was not statistically significant. Based on the number of subjects and the observed standard deviation for change in thenar oxygen saturation, this comparison had $80 \%$ power to detect a $0.8 \%$ difference between treatment groups, a difference not likely to be clinically significant. As shown in Figure 3, C, the changes in $\mathrm{S}_{\mathrm{t}} \mathrm{O}_{2}$ tended to be slightly greater for patients with lower pretransfusion values than patients with greater pretransfusion values; however, the slopes were very similar between treatment groups (interaction $P$ value .92).

Comparable results were observed for measurements of cerebral $\mathrm{S}_{\mathrm{t}} \mathrm{O}_{2}$ levels by NIRS (Table 4). The pretransfusion 
TABLE 1. Preoperative characteristics of RECAP study subjects

\begin{tabular}{|c|c|c|c|c|c|c|c|c|}
\hline \multirow[b]{2}{*}{ Characteristic* } & \multicolumn{4}{|c|}{$\begin{array}{c}\text { RECAP subjects who underwent } \\
\text { cardiac surgery and received } \geq 1 \mathrm{RBC} \\
\text { transfusion } 6 \mathrm{~h} \text { preoperatively to } 24 \mathrm{~h} \text { postoperatively }\end{array}$} & \multicolumn{4}{|c|}{ RECAP subjects who had an index transfusion } \\
\hline & $\begin{array}{r}\mathbf{R B C} \leq \mathbf{1 0} \mathrm{d} \\
\text { arm, } \mathrm{n}=\mathbf{4 7}\end{array}$ & $\begin{array}{l}\mathbf{R B C} \geq \mathbf{2 1 d} \\
\operatorname{arm}, \mathrm{n}=\mathbf{4 2}\end{array}$ & $P$ value $\dagger$ & $\begin{array}{c}\text { Effect } \\
\text { size }\end{array}$ & $\begin{array}{r}\mathbf{R B C} \leq \mathbf{1 0} \mathbf{d} \\
\operatorname{arm}, \mathbf{n}=\mathbf{2 3}\end{array}$ & $\begin{array}{r}\mathbf{R B C} \geq \mathbf{2 1} \mathbf{d} \\
\operatorname{arm}, \mathbf{n}=\mathbf{3 2}\end{array}$ & $P$ value $\dagger$ & $\begin{array}{c}\text { Effect } \\
\text { size } \\
\end{array}$ \\
\hline Age, y & $70(66,79)$ & $72(63,80)$ & .94 & 0.06 & $69(65,79)$ & $71(61,79)$ & .84 & 0.16 \\
\hline Male sex & $22(47 \%)$ & $19(45 \%)$ & 1.00 & 0.02 & $12(52 \%)$ & $14(44 \%)$ & .59 & 0.08 \\
\hline White & $40(85 \%)$ & $29(74 \%) \S$ & .28 & 0.13 & $20(87 \%)$ & $22(71 \%) \Upsilon$ & .20 & 0.19 \\
\hline Weight, kg & $81(69,92)$ & $75(68,86)$ & .41 & 0.22 & $80(70,92)$ & $81(70,86)$ & .90 & 0.06 \\
\hline Height, cm & $165(158,178)$ & $165(160,171)$ & .68 & 0.18 & $165(160,180)$ & $165(161,174)$ & .60 & 0.25 \\
\hline BMI, $\mathrm{kg} / \mathrm{m}^{2}$ & $28(25,31)$ & $28(25,32)$ & .84 & 0.14 & $28(25,31)$ & $28(25,32)$ & .60 & 0.04 \\
\hline Hemoglobin, g/dL & $11.2(10.4,12.1)$ & $11.8(10.7,12.8)$ & .26 & 0.23 & $10.9(10.2,12.1)$ & $11.6(10.4,12.5)$ & .20 & 0.37 \\
\hline Platelet count, $\times 10^{9} / \mathrm{L}$ & $198(166,243)$ & $225(173,256)$ & .33 & 0.19 & $196(148,235)$ & $225(170,249)$ & .16 & 0.40 \\
\hline Creatinine, $\mathrm{mg} / \mathrm{dL}$ & $1.2(1.0,1.5)$ & $1.0(0.8,1.3)$ & $<.01$ & 0.63 & $1.4(1.0,1.8)$ & $0.9(0.8,1.2)$ & $<.01$ & 1.06 \\
\hline $\begin{array}{l}\text { TRUST, mean ( } \pm \text { standard } \\
\text { deviation) }\end{array}$ & $4.00(0.72)$ & $3.71(0.86)$ & .04 & 0.36 & $3.96(0.71)$ & $3.63(0.91)$ & .05 & 0.41 \\
\hline $\begin{array}{l}\text { Baseline MODS, mean } \\
( \pm \text { standard deviation })\end{array}$ & $0.89(0.76)$ & $0.52(0.71)$ & .01 & 0.50 & $1.13(0.82)$ & $0.44(0.62)$ & $<.01$ & 0.98 \\
\hline Hypertension & $43(91 \%)$ & $38(90 \%)$ & 1.00 & 0.02 & $21(91 \%)$ & $28(88 \%)$ & 1.00 & 0.06 \\
\hline Diabetes & $21(45 \%)$ & $22(52 \%)$ & .53 & 0.08 & $13(57 \%)$ & $17(53 \%)$ & 1.00 & 0.03 \\
\hline \multicolumn{9}{|l|}{ Smoking history } \\
\hline Past smoker & $20(43 \%)$ & $12(29 \%)$ & .37 & 0.15 & $9(39 \%)$ & $10(31 \%)$ & .82 & 0.09 \\
\hline Current smoker & $7(15 \%)$ & $8(19 \%)$ & & & $4(17 \%)$ & $7(22 \%)$ & & \\
\hline No smoking history & $20(43 \%)$ & $22(52 \%)$ & & & $10(43 \%)$ & $15(47 \%)$ & & \\
\hline History of COPD & $14(30 \%)$ & $10(24 \%)$ & .63 & 0.07 & $8(35 \%)$ & $8(25 \%)$ & .55 & 0.11 \\
\hline $\begin{array}{l}\text { History of myocardial } \\
\text { infarction }\end{array}$ & $12(26 \%)$ & $14(33 \%)$ & .49 & 0.09 & $5(22 \%)$ & $8(25 \%)$ & 1.00 & 0.04 \\
\hline History of CHF & $12(26 \%)$ & $13(31 \%)$ & .64 & 0.06 & $9(39 \%)$ & $9(28 \%)$ & .56 & 0.12 \\
\hline History of stroke or TIA & $9(19 \%)$ & $6(14 \%)$ & .58 & 0.06 & $5(22 \%)$ & $4(13 \%)$ & .47 & 0.12 \\
\hline History of vascular surgery & $13(28 \%)$ & $8(19 \%)$ & .45 & 0.08 & $7(30 \%)$ & $6(19 \%)$ & .35 & 0.13 \\
\hline $\begin{array}{l}\text { Left ventricular ejection } \\
\text { fraction, } \%\end{array}$ & $55(35,55)$ & $48(34,55)$ & .45 & 0.11 & $44(30,55)$ & $50(35,55)$ & .34 & 0.35 \\
\hline Group O & $18(38 \%)$ & $17(40 \%)$ & .69 & 0.16 & $8(35 \%)$ & $14(44 \%)$ & .18 & 0.31 \\
\hline Group A & $22(47 \%)$ & $22(52 \%)$ & & & $10(43 \%)$ & $17(53 \%)$ & & \\
\hline Group B & $5(11 \%)$ & $3(7 \%)$ & & & $3(13 \%)$ & $1(3 \%)$ & & \\
\hline Group AB & $2(4 \%)$ & $0(0 \%)$ & & & $2(9 \%)$ & $0(\%)$ & & \\
\hline
\end{tabular}

RECAP, Red Cell Storage Duration Study Ancillary Physiologic Study; RBC, red blood cell; BMI, body mass index; TRUST, Transfusion Risk Understanding Score Tool; $M O D S$, Multiple Organ Dysfunction Score; COPD, chronic obstructive pulmonary disease; $C H F$, congestive heart failure; $T I A$, transient ischemic attack. *Unless otherwise noted, the median and first and third quartiles are reported for continuous characteristics and number and percent are reported for categorical characteristics. $\dagger P$ values for continuous variables are from a Kruskal-Wallis nonparametric test; $P$ values for categorical variables are from the Fisher exact test. $\ddagger$ Effect sizes for binary and categorical variables were calculated with the Cramer phi statistic and were calculated as the absolute difference in means divided by the pooled standard deviation for continuous variables. $§$ Data unknown for 3 subjects in the $\geq 21 \mathrm{~d}$ arm. $\lceil$ Data unknown for 1 subject in the $\geq 21 \mathrm{~d}$ arm.

cerebral $\mathrm{S}_{\mathrm{t}} \mathrm{O}_{2}$ levels were comparable between the 2 groups, although lower than the readings at the thenar eminence (around 62\%) and showed a statistically significant but small increase after transfusion in both groups. The increases in the mean cerebral $\mathrm{S}_{\mathrm{t}} \mathrm{O}_{2}$ from pre- to posttransfusion were only $2.6 \%(95 \% \mathrm{CI}, 1.3-3.9)$ in the $\leq 10$ day group and $1.6 \%(95 \% \mathrm{CI}, 0.5-2.7)$ in the $\geq 21$ day group and did not differ from one another.

The videomicroscopy images of the sublingual microcirculation were analyzed for 4 parameters characterizing blood flow. See Video 1 for an example. There were no clinically important changes in response to RBC transfusion, nor any apparent difference in that response between the 2 study groups, but the number of observations was too small to be statistically meaningful.

Similar comparisons were made for the changes in these parameters from within 6 hours before the start of surgery to $24 \pm 4$ hours after surgery to assess the possible cumulative effect of multiple units of RBCs. The subjects in both arms received on average approximately 4 units of RBCs in this time period (Table 3), which represents approximately one third of their RBC mass. There was a slightly greater change in the thenar eminence $\Delta \mathrm{S}_{\mathrm{t}} \mathrm{O}_{2}(3 \%-4 \%)$ than was observed before and after the transfusion of a single unit, but there 
TABLE 2. Characteristics of surgical procedures of RECAP subjects

\begin{tabular}{|c|c|c|c|c|c|c|c|c|}
\hline \multirow[b]{2}{*}{ Surgery characteristics* } & \multicolumn{4}{|c|}{$\begin{array}{c}\text { RECAP subjects who underwent } \\
\text { cardiac surgery and received } \geq 1 \mathrm{RBC} \\
\text { transfusion } 6 \mathrm{~h} \text { preoperatively to } 24 \mathrm{~h} \text { postoperatively }\end{array}$} & \multicolumn{4}{|c|}{ RECAP subjects who had an index transfusion } \\
\hline & $\begin{array}{l}\mathrm{RBC} \leq 10 \mathrm{~d} \\
\operatorname{arm}, \mathrm{n}=\mathbf{4 7}\end{array}$ & $\begin{array}{l}\mathrm{RBC} \geq 21 \mathrm{~d} \\
\operatorname{arm}, \mathrm{n}=\mathbf{4 2}\end{array}$ & $\begin{array}{c}P \\
\text { value } \dagger\end{array}$ & $\begin{array}{c}\text { Effect } \\
\text { size }\end{array}$ & $\begin{array}{l}\mathrm{RBC} \leq 10 \mathrm{~d} \\
\operatorname{arm}, \mathrm{n}=\mathbf{2 3}\end{array}$ & $\begin{array}{l}\mathrm{RBC} \geq \mathbf{2 1} \mathrm{d} \\
\operatorname{arm}, \mathrm{n}=\mathbf{3 2}\end{array}$ & $\begin{array}{c}P \\
\text { value } \dagger\end{array}$ & $\begin{array}{l}\text { Effect } \\
\text { size }\end{array}$ \\
\hline \multicolumn{9}{|l|}{ Procedure types } \\
\hline CABG only & $8(17 \%)$ & $8(19 \%)$ & .62 & 0.20 & $4(17 \%)$ & $6(19 \%)$ & .64 & 0.27 \\
\hline $\begin{array}{l}\text { Valve repair/ } \\
\text { replacement only }\end{array}$ & $7(15 \%)$ & $3(7 \%)$ & & & $2(9 \%)$ & $3(9 \%)$ & & \\
\hline $\begin{array}{l}\text { CABG + valve } \\
\text { replacement/repair }\end{array}$ & $3(6 \%)$ & $4(10 \%)$ & & & $0(0 \%)$ & $2(6 \%)$ & & \\
\hline $\begin{array}{l}\text { CABG + valve } \\
\text { replacement/ } \\
\text { repair }+ \text { other }\end{array}$ & $15(32 \%)$ & $9(21 \%)$ & & & $9(39 \%)$ & $6(19 \%)$ & & \\
\hline $\mathrm{CABG}+$ other & $8(17 \%)$ & $9(21 \%)$ & & & $4(17 \%)$ & $7(22 \%)$ & & \\
\hline $\begin{array}{l}\text { Valve replacement/ } \\
\text { repair + other }\end{array}$ & $6(13 \%)$ & $9(21 \%)$ & & & $4(17 \%)$ & $8(25 \%)$ & & \\
\hline \multicolumn{9}{|l|}{ Surgical access } \\
\hline $\begin{array}{l}\text { Primary median } \\
\text { sternotomy }\end{array}$ & $34(72 \%)$ & $33(79 \%)$ & .71 & .11 & $15(65 \%)$ & $24(75 \%)$ & .53 & 0.18 \\
\hline $\begin{array}{l}\text { Repeat median } \\
\text { sternotomy }\end{array}$ & $12(26 \%)$ & $9(21 \%)$ & & & $7(30 \%)$ & $8(25 \%)$ & & \\
\hline Thoracotomy & $1(2 \%)$ & $0(0 \%)$ & & & $1(4 \%)$ & $0(0 \%)$ & & \\
\hline \multicolumn{9}{|l|}{ Operative details } \\
\hline $\begin{array}{l}\text { Cardiopulmonary } \\
\text { bypass used }\end{array}$ & $47(100 \%)$ & $41(98 \%)$ & .47 & 0.11 & $23(100 \%)$ & $31(97 \%)$ & 1.00 & 0.12 \\
\hline $\begin{array}{l}\text { Cardiopulmonary } \\
\quad \text { bypass duration, } \S \text { min }\end{array}$ & $150.5(102.0,207.0) \Upsilon$ & $157.0(105.0,212.0)$ & .76 & 0.12 & $160.5(100.0,238.0) \uparrow$ & $157.0(102.0,212.0)$ & .67 & 0.22 \\
\hline $\begin{array}{l}\text { Aortic crossclamp } \\
\text { duration, min }\end{array}$ & $99.5(68.0,126.0) \Phi$ & $97.0(68.0,115.0)^{f}$ & .66 & 0.13 & $100.0(70.0,121.0) \rrbracket$ & $92.0(68.0,115.0) \uparrow$ & .48 & 0.20 \\
\hline Time in OR, $\mathrm{h}$ & $6.8(5.9,8.3)$ & $6.7(5.7,8.0)$ & .51 & 0.18 & $7.0(6.2,8.8)$ & $6.5(5.7,7.8)$ & .21 & 0.42 \\
\hline
\end{tabular}

RECAP, Red Cell Storage Duration Study Ancillary Physiologic Study; RBC, red blood cell; $C A B G$, coronary artery bypass grafting; $O R$, operating room. *The median and first and third quartiles are reported for continuous characteristics and number and percent are reported for categorical characteristics. $\dagger P$ values for continuous variables are from a Kruskal-Wallis nonparametric test; $P$ values for categorical variables are from the Fisher exact test. †̦ffect sizes for binary and categorical variables were calculated with the Cramer phi statistic and were calculated as the absolute difference in means divided by the pooled standard deviation for continuous variables. $\S$ Calculated only for patients undergoing cardiopulmonary bypass. $\Upsilon$ Data missing for 1 subject.

was not a significant difference between the 2 arms. Similarly, the modest changes in the other parameters of tissue oxygenation and microcirculatory blood flow were not

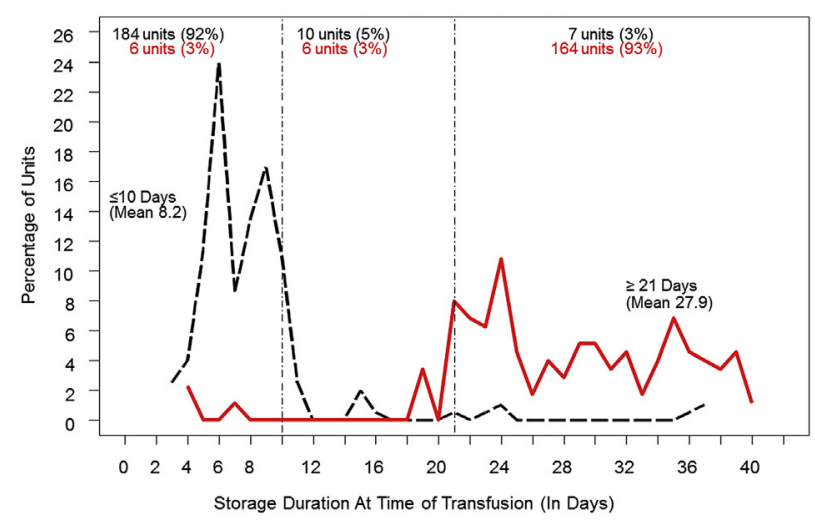

FIGURE 2. Storage duration of RBC units at time of transfusion. The black line and text refer to the $\leq 10$ day arm, and the red line and text refer to the $\geq 21$ day arm. different between the subjects receiving shorter- or longer-storage RBCs. The treatment group comparisons of physiologic changes also were not statistically significant in the per-protocol analyses (all $P$ values $>.35$ ).

\section{DISCUSSION}

This study used Food and Drug Administrationapproved, minimally invasive techniques for monitoring tissue hemoglobin oxygen saturation (NIRS) and blood flow through the microcirculation (SDF videomicroscopy). NIRS captures the level of hemoglobin oxygen saturation in small vessels and capillaries. It has been used in multiple clinical situations to gauge effectiveness of resuscitation efforts, vascular flow sufficiency, and transfusion efficacy in neonates, ${ }^{22}$ patients who are septic ${ }^{23}$ patients in critical care, ${ }^{24}$ patients undergoing surgery, ${ }^{25}$ and outpatients. ${ }^{26}$ SDF videomicroscopy has been used to interrogate the microcirculation of critically ill patients, especially those with sepsis, ${ }^{27}$ as well as to assess the effect of RBC 
TABLE 3. All transfusions from the time of entering the operating room until $24 \mathrm{~h}$ after leaving the OR

\begin{tabular}{|c|c|c|c|c|}
\hline Parameter & $\begin{array}{c}\mathrm{RBC} \leq 10 \mathrm{~d} \text { arm }(\mathrm{n}=201 \\
\text { units in } 47 \text { subjects })\end{array}$ & $\begin{array}{c}R B C \geq 21 \mathrm{~d} \text { arm }(n=176 \\
\text { units in } 42 \text { subjects })\end{array}$ & $P$ value* & Effect size \\
\hline \multicolumn{5}{|l|}{ Storage time of RBC } \\
\hline Mean, d $( \pm \mathrm{SD})$ & $8.2(4.7)$ & $27.9(7.4)$ & $<.01$ & 3.23 \\
\hline Median, d (Q1, Q3) & $7.0(6.0,9.0)$ & $28.0(23.0,34.0)$ & & \\
\hline Mean longest storage, $\mathrm{d}( \pm \mathrm{SD})$ & $9.0(5.6)$ & $31.90(7.1)$ & $<.01$ & 3.61 \\
\hline Mean shortest storage, $\mathrm{d}( \pm \mathrm{SD})$ & $6.5(2.0)$ & $25.2(6.6)$ & $<.01$ & 3.91 \\
\hline Units per protocol, n $(\%)$ & $184(92 \%)$ & $164(93 \%)$ & .55 & 0.03 \\
\hline $\begin{array}{l}\text { Transfused subjects receiving all } \\
\text { units per protocol, } \mathrm{n}(\%)\end{array}$ & $41(87 \%)$ & $39(93 \%)$ & .49 & 0.09 \\
\hline \multicolumn{5}{|l|}{ Units RBC transfused } \\
\hline Total units (U) & 201 & 176 & & \\
\hline Total subjects & 47 & 42 & & \\
\hline Mean U/subject, $\mathrm{n}( \pm \mathrm{SD})$ & $4.3(3.9)$ & $4.2(2.9)$ & .42 & 0.03 \\
\hline Median U/subject, n (Q1, Q3) & $3.0(2.0,6.0)$ & $3.5(2.0,5.0)$ & & \\
\hline Subjects $>6$ units, $\mathrm{n}(\%)$ & 9/47 (19\%) & $7 / 42(17 \%)$ & .79 & 0.03 \\
\hline Units out-of-ABO group, n (\%) & $9(4 \%)$ & $7(4 \%)$ & 1.00 & 0.01 \\
\hline Subjects out-of-ABO group, n (\%) & $4(9 \%)$ & $4(10 \%)$ & 1.00 & 0.02 \\
\hline \multicolumn{5}{|l|}{ Units $\nmid$ platelets transfused } \\
\hline Total units & 68 & 65 & & \\
\hline Total subjects, n (\%) & $30(64 \%)$ & $25(60 \%)$ & .83 & 0.04 \\
\hline Mean U/subject, $\mathrm{n}( \pm \mathrm{SD})$ & $2.3(2.0)$ & $2.6(2.5)$ & .56 & 0.15 \\
\hline Median U/subject, n (Q1, Q3) & $2.0(1.0,3.0)$ & $2.0(1.0,3.0)$ & & \\
\hline \multicolumn{5}{|l|}{ Units FFP transfused } \\
\hline Total units & 108 & 60 & & \\
\hline Total subjects, $\mathrm{n}(\%)$ & $28(60 \%)$ & $20(48 \%)$ & .29 & 0.12 \\
\hline Mean U/subject, $\mathrm{n}( \pm \mathrm{SD})$ & $3.9(3.9)$ & $3.0(2.2)$ & .52 & 0.26 \\
\hline Median U/subject, n (Q1, Q3) & $2.0(2.0,5.0)$ & $2.0(1.0,5.0)$ & & \\
\hline \multicolumn{5}{|l|}{ Units cryoprecipitate transfused } \\
\hline Total units & 13 & 16 & & \\
\hline Total subjects, n (\%) & $8(17 \%)$ & $12(29 \%)$ & .21 & 0.14 \\
\hline Mean U/subject, $\mathrm{n}( \pm \mathrm{SD})$ & $1.6(1.1)$ & $1.3(0.5)$ & .71 & 0.38 \\
\hline Median U/subject, n (Q1, Q3) & $1.0(1.0,2.0)$ & $1.0(1.0,2.0)$ & & \\
\hline
\end{tabular}

$O R$, Operating room; $R B C$, red blood cell; $S D$, standard deviation; $Q 1$, first quartile; $Q 3$, third quartile; $F F P$, fresh-frozen plasma. $* P$ values for continuous variables are from a Kruskal-Wallis nonparametric test; $P$ values for categorical variables are from the Fisher exact test. †Effect sizes for binary and categorical variables were calculated by use of Cramer phi statistic and were calculated as the absolute difference in means divided by the pooled standard deviation for continuous variables. $\ddagger 1 \mathrm{U} \equiv 1 \mathrm{U}$ apheresis platelets or 6 U whole blood platelets.

transfusion in the setting of sepsis, ${ }^{23,28}$ cardiac surgery, ${ }^{29}$ and trauma. ${ }^{30}$ Although RBC transfusion was associated with improved tissue $\mathrm{S}_{\mathrm{t}} \mathrm{O}_{2}$ levels in many of these studies, this was not the case in all of them. For example, when RBCs stored $>21$ days were transfused to trauma patients, tissue oxygen saturation decreased. ${ }^{11}$

The primary finding of this study is that there were no differences in tissue oxygen saturation or microvascular blood flow between patients who received $\mathrm{RBC}$ stored $\leq 10$ days versus $\geq 21$ days. This finding is consistent with the results of the parent trial, RECESS, which also found no differences in clinical outcomes including the primary outcome measure, change in the Multiple Organ Dysfunction Score through 7 days, or any of the other secondary outcomes. ${ }^{12}$ Although the RECAP subset was not large enough to compare these clinical outcomes independently with any statistical power, the similarity between the baseline patient characteristics and surgical characteristics of the RECAP study population and the entire RECESS cohort, as well as their comparable clinical outcomes (Table E1) suggests that storage of RBCs for 21 days or more does not affect their function in patients undergoing cardiac surgery, as measured by these clinical and physiologic endpoints. The results of 3 other large, randomized clinical trials in vulnerable populations, adult ${ }^{9}$ and neonatal ICU patients, ${ }^{8}$ and children with severe anemia ${ }^{10}$ likewise found no differences in clinical outcomes among subjects receiving RBC stored for shorter versus longer periods of time. Thus, the absence of measurable physiologic differences between patients receiving shorter- versus longer-storage RBC is reflected in the absence of observable clinical effects as well. The apparently equivalent clinical and physiologic effects of RBCs stored for greater or lesser amounts of time have been observed consistently in randomized trials 

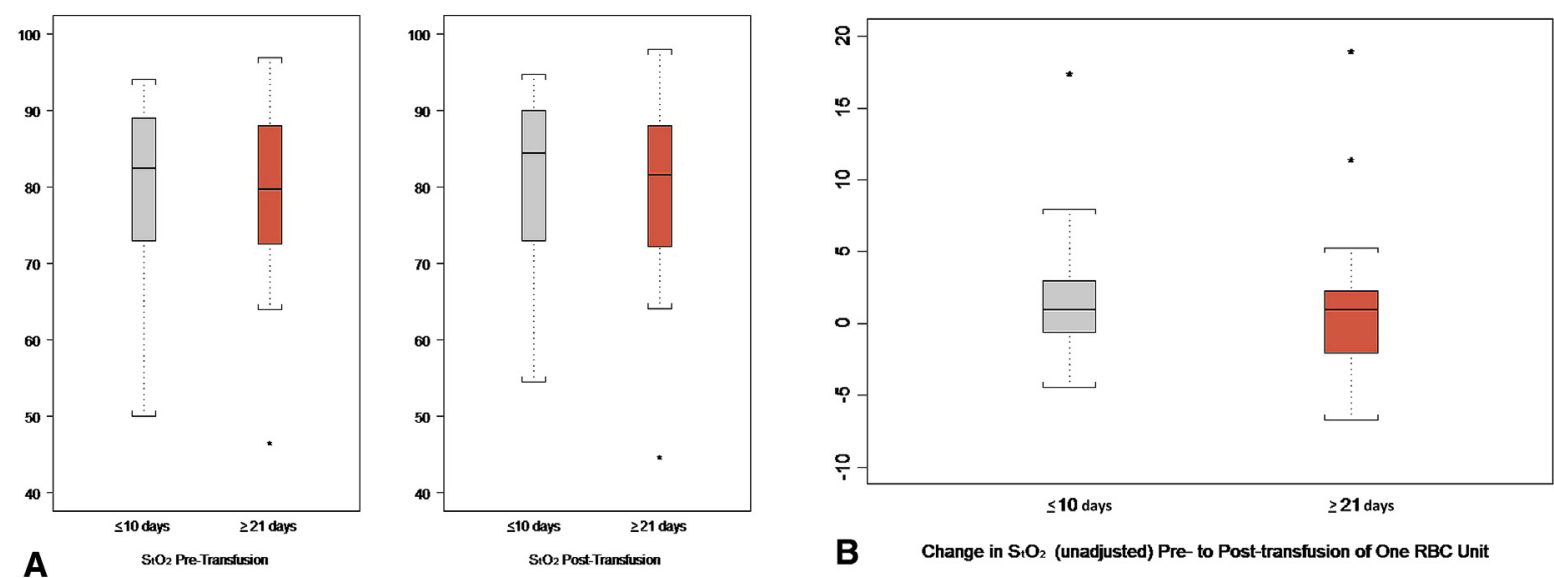

B Change in $\mathrm{S}_{1} \mathrm{O}_{2}$ (unadjusted) Pre- to Post-transfusion of One $\mathrm{RBC}$ Unit

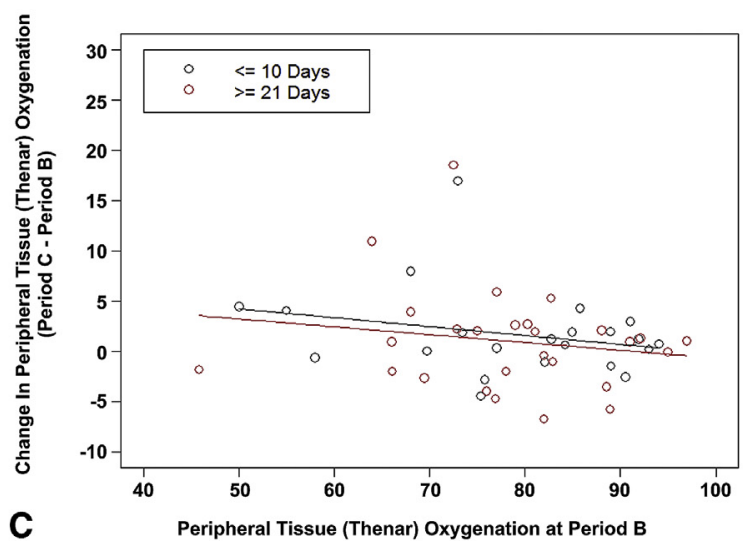

FIGURE 3. Thenar eminence $\mathrm{S}_{\mathrm{t}} \mathrm{O}_{2} . \mathrm{A}, \mathrm{S}_{\mathrm{t}} \mathrm{O}_{2}$ before and after a single unit $\mathrm{RBC}$ (index) transfusion. $\mathrm{B}$, Change in $\mathrm{S}_{\mathrm{t}} \mathrm{O}_{2}$ before and after a single unit $\mathrm{RBC}$ (index) transfusion. $\mathrm{C}$, Change in thenar oxygenation from before to after a single unit RBC (index) transfusion as a function of the pretransfusion oxygenation. Asterisks indicate single data points that were more than 3 interquartile ranges from either the top or the bottom of the interquartile range. $S_{t} O_{2}$, Oxygen saturation of tissue hemoglobin; $R B C$, red blood cell.

despite the well-described changes that occur in banked erythrocytes. This consistency makes it less likely that the clinical endpoints used to date have been too insensitive to detect subtle defects in RBC function at the tissue level.

The second finding is that independent of storage duration, RBC transfusion had very little effect on tissue oxygen saturation or microcirculatory flow in the subjects in this study. One possible reason is that banked RBCs, no matter how briefly they have been stored, fail to deliver oxygen to tissues. Another possibility is that even the techniques deployed in this study to assess these parameters were not sensitive to the effects of RBC transfusion. Among patients with very low hemoglobin levels or existing hypoxemia, however, RBC transfusion has been shown to improve tissue oxygenation as measured by NIRS ${ }^{11-14}$ and microcirculatory blood flow as visualized by SDF imaging. ${ }^{15,16} \mathrm{~A}$ third possible explanation for the absence of significant changes after RBC transfusion in this study is that most of these patients were neither oxygendeprived nor supply limited. This observation raises the question of the utility of these postoperative RBC transfusions. In a medically resource-rich setting, RBCs often are transfused to prevent tissue ischemia, despite the fact that the minimum hemoglobin concentration required to achieve this goal has not been defined in most clinical situations and may not be the best marker to identify which patients are likely to benefit from transfusion. Indeed, it can be argued that patients who are in bed and not exercising require relatively modest arterial oxygen content. Consistent with this supposition, studies comparing restrictive and liberal RBC transfusion strategies generally have found that there is no clinical detriment to maintaining patients at the lower of the 2 hemoglobin levels tested, ${ }^{31}$ including in the setting of cardiac surgery. ${ }^{32,33}$

One key strength of the study is its link to a large parent study that was powered for clinical endpoints and complemented the physiologic measurements reported here. In addition, RECAP was performed at 4 different facilities, enhancing the generalizability of the findings, and randomization was balanced by site, thereby minimizing the effects 
TABLE 4. Primary and secondary outcome measures for RECAP

\begin{tabular}{|c|c|c|c|c|}
\hline Outcome measures & $\mathrm{RBC} \leq 10 \mathrm{~d}$ arm & $\mathrm{RBC} \geq 21 \mathrm{~d}$ arm & $P$ value & Effect size* \\
\hline \multicolumn{5}{|l|}{ Change pre- to postindex RBC transfusion } \\
\hline Peripheral $\Delta \mathrm{S}_{\mathrm{t}} \mathrm{O}_{2}, \% \dagger$ & $1.7(-0.3,3.8), \mathrm{n}=22$ & $0.8(-1.1,2.7), \mathrm{n}=26$ & .52 & 0.18 \\
\hline Cerebral $\Delta \mathrm{S}_{\mathrm{t}} \mathrm{O}_{2}, \%$ & $2.6(1.3,3.9), \mathrm{n}=19$ & $1.6(0.5,2.7), \mathrm{n}=28$ & .23 & 0.27 \\
\hline$\Delta$ Microvascular flow index $\ddagger$ & $-0.05(-0.4,0.3), \mathrm{n}=5$ & $-0.1(-0.4,0.3), \mathrm{n}=6$ & .89 & 0.55 \\
\hline$\Delta$ Proportion perfused vessels, $\% \ddagger$ & $0.4(-12.9,13.7), \mathrm{n}=5$ & $-2.8(-14.8,9.1), \mathrm{n}=6$ & .71 & 0.80 \\
\hline$\Delta$ Perfused vessel density, $\mathrm{mm} / \mathrm{mm}^{2} \ddagger$ & $-2.7(-6.8,1.4), \mathrm{n}=5$ & $-3.5(-7.2,0.2), \mathrm{n}=6$ & .74 & 0.11 \\
\hline$\Delta$ Total vessel density, $\mathrm{mm} / \mathrm{mm}^{2} \ddagger$ & $-3.2(-8.2,1.8), \mathrm{n}=5$ & $-3.4(-8.0,1.2), \mathrm{n}=6$ & .94 & 0.21 \\
\hline \multicolumn{5}{|l|}{ Change preoperatively to $24 \mathrm{~h}$ postsurgery } \\
\hline Peripheral $\Delta \mathrm{S}_{\mathrm{t}} \mathrm{O}_{2}, \%$ & $3.3(-0.9,7.5), \mathrm{n}=14$ & $3.6(-0.2,7.5), \mathrm{n}=17$ & .91 & 0.01 \\
\hline Cerebral $\Delta \mathrm{S}_{\mathrm{t}} \mathrm{O}_{2}, \%$ & $0.3(-2.0,2.7), \mathrm{n}=19$ & $-0.5(-2.8,1.9), \mathrm{n}=19$ & .64 & 0.27 \\
\hline$\Delta$ Microvascular flow index $\ddagger$ & $0.1(-0.2,0.3), \mathrm{n}=6$ & $-0.01(-0.2,0.2), \mathrm{n}=11$ & .54 & 0.52 \\
\hline$\Delta$ Proportion perfused vessels, $\% \ddagger$ & $-3.5(-10.7,3.7), \mathrm{n}=6$ & $-1.6(-6.9,3.7), \mathrm{n}=11$ & .65 & 0.03 \\
\hline$\Delta$ Perfused vessel density, $\mathrm{mm} / \mathrm{mm}^{2} \ddagger$ & $-0.7(-5.5,4.1), \mathrm{n}=6$ & $-1.6(-5.1,1.9), \mathrm{n}=11$ & .74 & 0.35 \\
\hline$\Delta$ Total vessel density, $\mathrm{mm} / \mathrm{mm}^{2} \ddagger$ & $0.3(-4.9,5.4), \mathrm{n}=6$ & $-1.3(-5.1,2.4), \mathrm{n}=11$ & 61 & 0.21 \\
\hline
\end{tabular}

All are mean values $(95 \% \mathrm{CI})$ adjusted for baseline. $\mathrm{RECAP}$, Red Cell Storage Duration Study Ancillary Physiologic Study; $R B C$, red blood cells; $S_{t} \mathrm{O}_{2}$, tissue $\mathrm{O}_{2}$ saturation as measured by NIRS. *Effect sizes for binary and categorical variables were calculated with the Cramer phi statistic and were calculated as the absolute difference in means divided by the pooled standard deviation for continuous variables. †Primary outcome measure. $\ddagger$ As measured by SDF imaging.

of differences in patient populations and clinical practices among participating hospitals. Adherence to the study intervention was excellent, with greater than $90 \%$ of RBC units transfused to the study subjects having been stored for the assigned period of time, and achieved a wide separation in the median RBC storage times ( 21 days) between the 2 arms.

There are several limitations, however, to the study. Enrollment was lower than anticipated and additional sites could not be added because of the limitation in the number of devices available for the study. In addition, fewer patients received postoperative $\mathrm{RBC}$ transfusions than originally projected based on historical data, which may be attributable to the implementation of patient blood-management programs ${ }^{34}$ and the gradual adoption of more conservative transfusion practices based on clinical trials data. ${ }^{32,33}$ Missing data points also highlight the logistical challenges of obtaining some of these timed

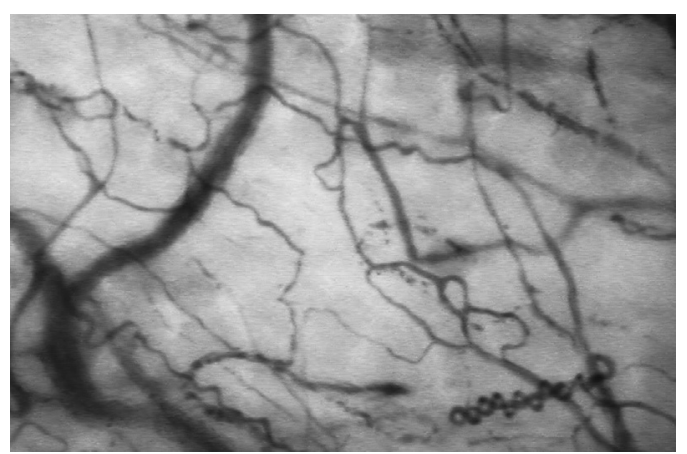

VIDEO 1. Blood flow in sublingual microcirculation as visualized by side-stream darkfield imaging and videomicroscopy. Video available at: http://www.jtcvsonline.org/article/S0022-5223(16)31619-1/addons. measurements in unstable patients in the ICU setting, especially for the videomicroscopy, which requires active intervention.

\section{CONCLUSIONS}

The use of noninvasive technology to assess tissue oxygen saturation and microcirculatory blood flow in the RECAP cohort of patients has enabled the measurement of physiologic correlates to the clinical outcomes observed in the parent study, RECESS. The physiologic measurements are consistent with the clinical endpoints; both show that outcomes are not different among cardiac surgery patients in the ICU who receive RBC stored for $\leq 10$ days versus $\geq 21$ days.

\section{Conflict of Interest Statement}

Dr Nathan I. Shapiro reports consulting fees from Cumberland Pharma and Thermo-Fisher. All other authors have nothing to disclose with regard to commercial support.

The authors acknowledge the leadership of the Transfusion Medicine and Hemostasis Clinical Trials Network and Red Cell Storage Duration Study for its input into the early design phases and their ongoing support. We would especially like to recognize the early guidance of Dr Gregory Bielman (U MN). The authors thank the nurses and physicians in the operating rooms and intensive care units of the 4 enrolling institutions for their cooperation and support. We also recognize the contributions of individuals whose efforts were material to the successful realization of this study: Cristina Brueggeman, RN (MGH); Marcy Lindley; the research coordinators from the Multidisciplinary Acute Care Research Organization, Arthur Boujoukos, MD, Penny Sappington, MD, Vinay Badhwar, MD, and Lawrence Wei, MD (U Pittsburgh); Rika Ohkuma, MD (Johns Hopkins); Kerri Hayes, BS and Brian Harty, MS (New England Research Institutes). 


\section{References}

1. Bennett-Guerrero E, Veldman TH, Doctor A, Telen MJ, Ortel TL, Reid TS, et al. Evolution of adverse changes in stored RBCs. Proc Nat Acad Sci USA. 2007;104: 17063-8.

2. Zimrin AB, Hess JR. Current issues relating to the transfusion of stored red blood cells. Vox Sang. 2009;96:93-103.

3. Triulzi D, Yazer MH. Clinical studies of the effect of blood storage on patient outcomes. Transfus Aph Sci. 2010;43:95-106.

4. Wang D, Sun J, Soloman SB, Klein HG, Natanson C. Transfusion of older stored blood and risk of death: a metanalysis. Transfusion. 2012;52:1184-95.

5. van de Watering L, Lorinser J, Versteegh M, Westendord R, Brand A. Effects of storage time of red blood cell transfusions on the prognosis of coronary artery bypass graft patients. Transfusion. 2006;46:1712-8.

6. Koch CG, Li L, Sessler DI, Figueroa P, Hoeltge GA, Mihaljevic T, et al. Duration of red-cell storage and complications after cardiac surgery. N Engl J Med. 2008; 358:1229-39.

7. Steiner M, Ness PM, Assmann SF, Triulzi DJ, Sloan SR, Delaney M, et al. Duration of red-cell storage and cardiac surgery outcomes. N Engl J Med. 2015;372: 1419-29.

8. Fergusson DA, Hébert P, Hogan DL, LeBel L, Rouvinez-Bouali N, Smyth JA, et al. Effect of fresh red blood cell transfusions on clinical outcomes in premature, very low-birth-weight infants: the ARIPI randomized trial. J Am Med Assoc. 2012;308:1443-51.

9. Lacroix J, Hébert P, Fergusson D, Tinmouth A, Cook DJ, Marshall JC, et al. Age of transfused blood in critically ill adults. N Engl J Med. 2015;372:1410-8.

10. Dhabangi A, Ainomugisha B, Cserti-Gzdewich C, Ddungu H, Kyeyune D, Musisi E, et al. Effect of transfusion of red blood cells with longer vs shorter storage duration on elevated blood lactate levels in children with severe anemia: the TOTAL randomized clinical trial. J Am Med Assoc. 2015;314:2514-23.

11. Kiraly LN, Underwood S, Differding JA, Schreiber MA. Transfusion of aged packed red blood cells results in decreased tissue oxygenation on critically injured trauma patients. J Trauma. 2009;67:29-32.

12. Roberson RS, Lockhart E, Shapiro NI, Bandarenko N, McMahon TJ, Massey MJ, et al. Impact of transfusion of autologous 7-versus 42-day old AS-3 red blood cells on tissue oxygenation and the microcirculation in healthy volunteers. Transfusion. 2013;52:2459-64.

13. Weinburg JA, MacLennan PA, Vandromme-Cusick MJ, Magnotti LJ, Kerby JD, Rue LW, et al. The deleterious effect of red blood cell storage on microvascular response to transfusion. J Trauma Acute Care Surg. 2013;75:807-12.

14. Dhabangi A, Ainomugisha B, Cserti-Gazdewich C, Ddungu H, Kyeyune D, Musisi A, et al. Cerebral oximetry in Ugandan children with severe anemia: clinical categories and response to transfusion. JAm Med Assoc Pediatr. 2016;170:995-1002.

15. Yuruk K, Milstein DMJ, Bezemer R, Bartels SA, Biemond BJ, Ince C. Transfusion of banked red blood cells and the effects on hemorrheology and microvascular dynamics in anemic hematology outpatients. Transfusion. 2013;53:1346-52.

16. Ayhan B, Yuruk K, Koene S, Sahin A, Ince C, Aypar U. The effect of nonleukoreduced red blood cell transfusions on microcirculation in mixed surgical patients. Transfus Aph Sci. 2013;49:212-22.

17. Alghamdi AA, Davis A, Brister S, Corey P, Logan A. Development and validation of Transfusion Risk Understanding Scoring Tool (TRUST) to stratify cardiac surgery patients according to their blood transfusion needs. Transfusion. 2006; 46:1120-9.

18. Zelen M. The randomization and stratification of patients to clinical trials. $J$ Chronic Dis. 1974; 27:365-75.
19. Goedhart PT, Khalilzada M, Bezemer R, Merza J, Ince C. Sidestream Dark Field (SDF) imaging: a novel stroboscopic LED ring-based imaging modality for clinical assessment of the microcirculation. Optics Express. 2007;15: 15101-14.

20. De Backer D, Hollenberg S, Boerma C, Goedhart P, Büchele G, Ospina-Tasco G, et al. How to evaluate the microcirculation: report of a round table conference. Crit Care. 2007;11:R101-10.

21. Marshall JC, Cook DJ, Christou NV, Bernard JR, Sprung CL, Sibbald WJ. Multiple organ dysfunction score: a reliable descriptor of complex clinical outcome. Crit Care Med. 1995;23:1638-52.

22. Sandal G, Oguz SS, Erdeve O, Akar M, Uras N, Dilmen U. Assessment of red blood cell transfusion and transfusion duration on cerebral and mesenteric oxygenation using near-infrared spectroscopy in preterm infants with symptomatic anemia. Transfusion. 2014;54:1100-5.

23. Donati A, Damiani E, Luchetti MM, Domizi R, Scorcella C, Carsetti A, et al. Microcirculatory effects of the transfusion of leukodepleted or nonleukodepleted red blood cells in patients with sepsis: a pilot study. Crit Care 2014;18:R33-43.

24. Creteur J, Neves AP, Vincent JL. Near infrared spectroscopy technique to evaluate the effects of red blood cell transfusion on tissue oxygenation. Crit Care. 2009;13(suppl 5):S11-8.

25. Torella F, Haynes SL, McCollum CN. Cerebral and peripheral oxygen saturation during red cell transfusion. J Surg Res. 2003;110:217-21.

26. Yuruk K, Bartels SA, Milstein DMJ, Bezemer R, Biemond BJ, Ince C. Red blood cell transfusions and tissue oxygenation in anemic hematology outpatients. Transfusion. 2012;52:641-6.

27. Sakr Y, Dubois MJ, De Backer D, Creteur J, Vincent JL. Persistent microcirculatory alterations are associated with organ failure and death in patients with septic shock. Crit Care Med. 2004;32:1825-31.

28. Sakr Y, Chierego M, Piagnerelli M, Verdant C, Dubois MJ, Koch M, et al. Microvascular response to red blood cell transfusion in patients with severe sepsis. Crit Care Med. 2007;35:1639-44.

29. Yuruk K, Almac E, Bezemer R, Goedhart P, de Mol B, Ince C. Blood transfusions recruit the microcirculation during cardiac surgery. Transfusion. 2011;41:961-7.

30. Weinburg JA, MacLennan PA, Vandromme-Cusick MJ, Angnotti JM Magnotti LJ, Kerby JD, et al. Microvascular response to red blood cell transfusion in trauma patients. Shock. 2012;37:276-81.

31. Carson JL, Carless PA, Hébert PC. Transfusion thresholds and other strategies for guiding allogeneic red blood cell transfusion. Cochrane Database Syst Rev. 2012;4:CD002042.

32. Hajjar LA, Vincent JL, Galas FR, Nakamura RE, Silva CM, Santos MH, et al. Transfusion requirements after cardiac surgery: the TRACS randomized controlled trial. J Am Med Assoc. 2010;304:1559-67.

33. Murphy GJ, Pike K, Rogers CA, Wordsworth S, Stokes WA, Angelini GD, et al Liberal or restrictive transfusion after cardiac surgery. N Engl J Med. 2015;372: 1997-2108.

34. Ness PM, Frank SM. Enhancing patient blood management: a long-term FOCUS Lancet. 2015;355:157-9.

Key Words: transfusion, microcirculation, tissue oxygenation, RBC storage 


\section{APPENDIX E1. MATERIALS AND METHODS Tissue Hemoglobin Oxygen Saturation: Data Analysis}

Raw data were uploaded to a cloud-based server and synchronized to a secure server at the central processing facility. The data files for tissue hemoglobin oxygen saturation $\left(\mathrm{S}_{\mathrm{t}} \mathrm{O}_{2}\right)$ of the thenar eminence and cerebrum were parsed for absolute time and value data entries and converted to a common file format for analysis. Time data embedded in the $\mathrm{S}_{\mathrm{t}} \mathrm{O}_{2}$ datastreams were correlated with data that were recorded directly on Case Report Forms which indicated the time points defined in the Materials and Methods section of the main text. Using a custom software application written in Matlab (Mathworks, Natick, Mass), $\mathrm{S}_{t} \mathrm{O}_{2}$ data were plotted as a function of time. Color-coded vertical marks delineated the times that the sensors were applied or removed, the 4 time points described previously, all recorded transfusion start and stop times, and the time the patient entered the intensive care unit. An analyst visually inspected the data plots for stability and selected a region of the plot for each measurement that was stable and within the time point window using a running average single spot measurement. The 150 -sample average was taken over a period of 2.5 minutes before to 2.5 minutes after the spot to be measured.

For time point A, the spot measurement was selected during a stable period in the signal within 6 hours before the incision and at least $2.5 \mathrm{mi}-$ nutes after the start of data recording and at least 2.5 minutes before entering the OR. For time point $\mathrm{B}$, the spot measurement was selected during a stable period in the signal within 2 hours before the index transfusion AND at least 2.5 minutes before the start of the index transfusion. For time point $\mathrm{C}$, the spot measurement was selected during a stable period in the signal within 2 hours after the index transfusion AND at least 2.5 minutes after the end of the index transfusion. For time point D, the spot measurement was selected during a stable period in the signal most proximal to 24 hours after arrival to the intensive care unit AND at least 2.5 minutes after the beginning of time point $\mathrm{D}$. The software then computed and recorded an average $\mathrm{S}_{\mathrm{t}} \mathrm{O}_{2}$ value for that region of the plot.

\section{Microcirculatory Blood Flow: Data Analysis}

The Microscan video files were preprocessed to enhance contrast, edited to 5 seconds' duration, and evaluated for image quality using the method described. ${ }^{\mathrm{E} 1}$ Video files with unacceptable quality were excluded from further analysis. Video clips were sorted by quality score and up to 3 clips were selected at each of the 4 time points. Selected video files were assigned a random identification number before further analysis via AVA 3.1 software (Microvision Medical BV, Amsterdam, The Netherlands). Vessel centerlines and lumen boundaries were drawn by the use of semiautomated or manual tools in AVA. All of the microcirculatory parameters reported in this study were derived from analyses of small vessels (defined as having lumen diameters below $20 \mu \mathrm{m}$ ) because capillaries and postcapillary venules of this size are the primary sites of oxygen diffusion between blood and tissue. Blood flow in vessel segments was evaluated in a semiquantitative fashion using a scale of 0 to 3 ( 0 : no flow, 1: intermittent flow, 2: sluggish flow, 3: continuous flow). Microcirculatory parameters were then derived from the measured small vessel total length and the perfused length.

\section{E-Reference}

E1. Massey MJ, Larochelle E, Najarro G, Karmacharla A, Arnold A, Trzeciak S, et al. The microcirculation imaging quality score: development and primary evaluation of a proposed approach to grading quality of image acquisition for bedside videomicroscopy. J Crit Care. 2013;28:913-7. 
TABLE E1. Comparison of transfused subjects in RECESS (parent study) and RECAP (ancillary study)

Parameter

Baseline characteristics

Age, y, median (Q1, Q3)

Male, n $(\%)$

Hemoglobin, g/dL, median (Q1, Q3)

Creatinine, mg/dL, median (Q1, Q3)

TRUST, mean $( \pm \mathrm{SD})$

MODS, mean $( \pm \mathrm{SD})$

Surgery characteristics

Repeat sternotomy, n (\%)

Cardiopulmonary bypass duration, min,* median (Q1, Q3)

Transfusion data (from time entering the OR until $24 \mathrm{~h}$ after leaving the OR)

RBC transfused, median units (Q1, Q3)

Shorter storage time, d, mean $( \pm \mathrm{SD})$

Longer storage time, $d$, mean $( \pm S D)$

Outcome measures

$\Delta$ MODS $7 \mathrm{~d}$, mean $( \pm \mathrm{SD})$

ICU length of stay, d, median (Q1, Q3)

Mortality $7 \mathrm{~d}, \mathrm{n}(\%)$

These subjects received at least one $\mathrm{RBC}$ transfusion from $6 \mathrm{~h}$ before surgery to $24+4 \mathrm{~h}$ after surgery. $R E C E S S$,

RECESS subjects, $n=1098$

RECAP subjects, $\mathbf{n}=\mathbf{8 9}$

$$
\begin{gathered}
72(66,79) \\
475(43 \%) \\
11.9(10.7,12.9) \\
1.0(0.8,1.4) \\
3.98( \pm 0.91) \\
0.67( \pm 0.81)
\end{gathered}
$$

$293(27 \%)$

$140(102,190)$

$$
\begin{gathered}
3.0(2.0,5.0) \\
16.2( \pm 11.1) \\
20.0( \pm 12.8)
\end{gathered}
$$

$8.58( \pm 3.58) \dagger$

$3(2,5)$

$26(2.4 \%)$
$71(66,80)$

$41(46 \%)$

$11.5(10.5,12.4)$

$1.1(0.9,1.4)$

$3.87( \pm 0.80)$

$0.72( \pm 0.75)$

$21(24 \%)$

$151(102,209)$

$3.0(2.0,5.0)$

$15.3( \pm 10.5)$

\begin{tabular}{|c|c|c|c|c|}
\hline \multirow{2}{*}{$\begin{array}{c}\text { Clinical characteristics within } 2 \text { h of start } \\
\text { of postoperative RBC transfusion }\end{array}$} & \multicolumn{3}{|c|}{ RECAP subjects who had an index transfusion } & \multirow[b]{2}{*}{ Effect size } \\
\hline & $\leq \mathbf{1 0} \mathrm{d}$ arm, $\mathrm{n}=\mathbf{2 3}$ & $\geq 21 \mathrm{~d}$ arm, $\mathbf{n}=\mathbf{3 2}$ & $P$ value* & \\
\hline Receiving supplemental oxygen, n (\%) & $20(87 \%)$ & $31(97 \%)$ & .30 & 0.19 \\
\hline Unknown & 0 & 0 & & \\
\hline Intubated, n (\%) & $17(74 \%)$ & $26(81 \%)$ & .53 & 0.09 \\
\hline Unknown & 0 & 0 & & \\
\hline Receiving inotrope, $\mathrm{n}(\%)$ & $17(77 \%)$ & $21(70 \%)$ & .75 & 0.08 \\
\hline Unknown & 0 & 0 & & \\
\hline Systolic BP, mm Hg, mean $( \pm \mathrm{SD})$ & $104.8(15.9)$ & $109.4(22.6)$ & .53 & 0.23 \\
\hline Diastolic BP, mm Hg, mean $( \pm \mathrm{SD})$ & $50.4(8.6)$ & $51.9(13.8)$ & .76 & 0.13 \\
\hline Heart rate, bpm, mean $( \pm S D)$ & $85.3(12.6)$ & $88.9(11.3)$ & .46 & 0.30 \\
\hline $\mathrm{FiO}_{2}$, mean $( \pm \mathrm{SD})$ & $48.5(15.7)$ & $46.1(14.2)$ & .57 & 0.16 \\
\hline \multicolumn{5}{|l|}{ Blood oxygen saturation } \\
\hline $\mathrm{S}_{\mathrm{a}} \mathrm{O}_{2}$, mean $( \pm \mathrm{SD})$ & $100(0), \mathrm{n}=2$ & $97(2.9), \mathrm{n}=6$ & .09 & 1.13 \\
\hline $\mathrm{S}_{\mathrm{p}} \mathrm{O}_{2}$, mean $( \pm \mathrm{SD})$ & $98.5(2.1), \mathrm{n}=17$ & $98.6(3.2), \mathrm{n}=25$ & .23 & 0.03 \\
\hline Unknown & 3 & 0 & & \\
\hline
\end{tabular}

$19.8( \pm 13.1)$

$8.74( \pm 3.55)$

$2(1,4)$

$2(2.3 \%)$ Duration Study Ancillary Physiologic Study; Q1, first quartile; Q3, third quartile; TRUST, Transfusion Risk Understanding Score Tool; SD, standard deviation; MODS, Multiple Organ Dysfunction Score; $O R$, operating room; $R B C$, red blood cells; $I C U$, intensive care unit. *Calculated only for patients undergoing cardiopulmonary bypass. $\nmid$ For the change in MODS at $7 \mathrm{~d}$, data were unavailable for 11 subjects. $\ddagger$ For the change in MODS at $7 \mathrm{~d}$, data were unavailable for 1 subject.

TABLE E2. Patient clinical characteristics before postoperative RBC (index) transfusion 